\title{
Fraud in Healthcare Service
}

\author{
Dara Pustika Sukma ${ }^{1 *}$, Adi Sulistiyono ${ }^{2}$, and Widodo Tresno Novianto ${ }^{2}$ \\ ${ }^{1}$ Law Science Doctoral Program, Sebelas Maret University, Surakarta, Indonesia \\ ${ }^{2,}$ Faculty of Law, Sebelas Maret University, Surakarta, Indonesia
}

\begin{abstract}
In Indonesia, the fraud of healthcare service implementation occurs widely in hospitals, thereby harming the participants of social insurance. The objectives of research were to find out, to analyze, and to give solution to the fraud in the healthcare service. This research was taken place in several hospitals in Central Java Indonesia using non-doctrinal or empirical method on stakeholders related to national health insurance. The result of research showed that the substance of the ratification of Health Minister's Regulation Number 36 of 2015 about Fraud Prevention in National Health Insurance in National Social Insurance System becomes the government's attempt in suppressing fraud in healthcare service. In its structure, healthcare service occurs due to the pressure of enacted costing system, limited supervision, and justification in committing fraud and the imbalance between health service system and burden among clinicians, service provider not giving adequate incentive, inadequate medical equipment supply, system inefficiency, less transparency in health facilities, and cultural factor. Those who are responsible for the attempt of eradicating fraud such as Health Ministry, Regency/City Health Service, Hospital's Board of Directors, Hospital Supervision Agency and Council, Social Insurance Administration Organization, professional organization, and Social Insurance participants should walk in the cycle starting from building awareness, reporting, detecting, investigating, sanction imposing, to building awareness.
\end{abstract}

\section{Introduction and literature review}

The State is responsible for organizing anything related to the fulfillment of right to healthy life for its people, including the poor and destitute ones [1].

The awareness of the importance of social insurance develops continuously corresponding to the amendment to 1945 Constitution in Article 34 clause (2) mentioning that the state shall develop a system of social security for all of the people. National Social Insurance System (thereafter called SJSN) in the amendment to 1945 Constitution, the publication of Law Number 40 of 2004 about National Social Insurance System (thereafter called UU SJSN) [2] strongly prove that government and related stakeholders are highly committed to realize social welfare for all of its people. SJSN is a form of social protection essentially aiming to ensure that all people can meet their basic life needs reasonably.

\footnotetext{
*Corresponding author: darapustika@gmail.com
} 
Jamkesmas is social health insurance for poor and destitute people, the due of which is paid by Government.

Insurance, according to Article 246 of Indonesian Commercial Code (thereafter called KUH Dagang) and Article 1 clause (1) of Law Number 2 of 1992 about Insurance Business, is an agreement between the insurer and the insured over a risk guaranteed, constituting a business highly depending on the principle of mutual trust between insurance company (Insurer) and policy holder (Insured), in which insurance company will pay a number of benefits to police holder as written on insurance policy and for that reason, policy holder obligatorily pays an amount of premium to insurance company. In this case, policy holder hands over the loss he/she suffers from in the future to insurance company and believes that insurance company will pay for the loss. Meanwhile, insurance company believes that the policy holder will not make fraud. The development of insurance business indicates the public's improved awareness of the importance of health and life protection. In addition, another objective of opening insurance policy is to protect the beneficiaries' future when they lose their main breadwinner. On the other hand, this insurance business development in practice is followed with deception or in insurance business called insurance fraud. The wish to get profit as much as possible is a factor encouraging the development of Insurance Fraud.

Fraud (English) or fraude (Dutch) is the form of deception against insurance fraud has been actually anticipated in Article 251 of Indonesian Commercial Code (thereafter called KUH Dagang) [3], stating that any wrong or incorrect notifications or any disguised conditions known by the insured, despite good will, with such characteristics that the agreement will not be established or is not established with the same requirements, if the insurer knows the actual conditions, void the insurance.

The Association of Certified Fraud Examiners (ACFE), a professional organization operating in fraud supervision and aiming to eradicate fraud headquartered in United States of America and having subsidiary in Indonesia, classifies fraud into some categories called Fraud Tree. Fraud Tree consisted of firstly asset misappropriation. Asset misappropriation includes the misuse/stealing of company or other party's asset or property. It is the form of Fraud detected most easily because of its tangible characteristic or defined value. Secondly, Fraudulent statement involves an action committed by a company's official or executive or government institution to hide or disguise actual financial condition by conducting financial engineering in presenting its financial statement to get profit or can likely be analogized with window dressing. Thirdly, corruption is the type of fraud detected most difficultly because it pertains to the cooperation with other parties such as bribery and corruption and constituting the fraud occurring most widely in developing countries where the law enforcement is still weak and there is a poor awareness of good governance so that its integrity factor is still questioned. Such the fraud cannot be detected because the parties in cooperation enjoy mutual benefit or mutualism symbiosis. It includes conflict of interest, bribery, illegal gratuities, and economic extortion.

Generally, Fraud is a crime using dishonest methods to benefit from others. Particularly, fraud in health insurance is defined as an action of deceiving or getting healthcare service program benefit in incorrect manner [4].

Considering the Republic of Indonesia Health Minister's Regulation Number 36 of 2015 about Fraud Prevention in National Health Insurance Program in National Social Insurance System, Fraud in health insurance is an action committed deliberately by participants, employees of Social Insurance Administration Organization for Health (thereafter called BPJS Kesehatan), healthcare service provider, and drug and health equipment supplier to get financial benefit from JKN program in SJSN through deception inconsistent with the provision. 
Deliberate attempt of making fault or giving wrong information done by an individual or an institution whom know that it is wrong, and that can result in a number of illegal benefit from the individual, the institution or other parties (National Health Care Antifraud of America / NHCAA) is a deliberate attempt and action to do fault or deception in order to get illegal profit or benefit by deceiving others, thereby harming others. Fraud can be defined as an intentionally fraudulent activity to get financial benefit. Thus, there some elements in fraud: Perpetrator is an individual or an institution intentionally making guilt or mistake that should not be done; motivation or intention, that the fraud is committed intentionally with motive or intention to get profit or benefit for themselves or others; guilt fact is a real evident or fact about the guilt committed by perpetrator, and perpetrator admits it; and loss, other parties suffer from a number of losses due to the perpetrator's guilt. Generally, fraud occurs when situation and condition give the perpetrator the opportunity of doing fraud [5].

Meanwhile, background conditions enabling the perpetrator to do fraud are, among others: unclear work procedure, weak internal supervision or supervision thereby enabling the perpetrator to do fraud.

Fraud, according to Advantage Concise Oxford Dictionary, occurs in a wide variety of forms and is ever changing as new technologies and new economic and social systems provide new opportunities for fraudulent activity. The total extent of business losses due to fraudulent activities is difficult to determine. One estimate claims that financial losses range from \$100-150 billion per year. The Association of Certified Fraud Examiners estimates that US organizations lose about $7 \%$ of their revenues to fraud. If this were to hold true for all organizations contributing to the gross domestic product of about $\$ 21$ trillion for 2016, fraud losses could be as high as $\$ 1.5$ trillion [6].

Fraud in Taiwan is represented as the nature and prevalence of insurance fraud has been studied only to a limited extent, even in the USA and Europe. Nevertheless, national authorities have pressed ahead with various approaches to control such fraud [7].

In many countries most populations do not have access to health insurance. Peru has made an effort to change this in the early 2000s. The institutional setup gives rise to the rare opportunity to study the effects of health insurance coverage exploiting a sharp regression discontinuity design. We find large effects on utilization that are most pronounced for the provision of curative care. Individuals seeing a doctor lead to an increased awareness of health problems and generate a potentially desirable form of supplier-induced demand: they decide to pay themselves for services that are in short supply [8].

Fraud can be seen in all insurance types including health insurance. Fraud in health insurance is done by intentional deception or misrepresentation for gaining some shabby benefit in the form of health expenditures [9].

Fraudulent claims are a pervasive problem within No- Fault insurance in New York. It has risen to such an extreme amount that the New York State Legislature has stepped in to ensure that every insurance company has developed a unit of personnel to investigate and eliminate the high amount of fraudulent claims within the state. The insurance companies need cooperation from law enforcement, arbitrators, and the courts to lessen the amount of insurance fraud. This will, in turn, decrease the costly insurance policies within the state [10].

In United States, as the Supreme Court recently reminded us, the FCA "is not a means of imposing treble damages and other penalties for insignificant regulatory or contractual violations." And while the FCA addresses acts of fraud against the government that drains the federal treasury, the Supreme Court has also reminded us that it is definitively not "an all-purpose antifraud statute" to enforce every regulation on the books. Instead, as the Court 
has made clear in a series of cases even before Escobar, the FCA applies only when the alleged breach would result in the government denying or reducing payment [11].

Fraud phenomenon also occurs in Indonesia, including in Central Java. The implementation of Health Insurance Program in Indonesia shows 889,442 fraud incidences with total frequency of 1,217,773 times since December 31, 2015. Potential inefficiency reaches IDR 1,246 trillions with 1,845,140 incidences up to November 2016 [12].

\section{Objective of study}

This article gives an insight into Healthcare service fraud to those who are responsible for it, gives knowledge to law academicians, and contributes thinking to stakeholders particularly paramedics, BPJS and government in dealing with fraud problems arising in healthcare service in order to cooperate in the attempt of eradicating healthcare service fraud.

\section{Methodology}

This research was taken place in several hospitals in Central Java, Indonesia using nondoctrinal or empirical methods on stakeholders related to national health insurance. The author conducted an in-depth interview to find out, to study, and to assess the management and to get recommendation to solve fraud problems in healthcare service. Data analysis was conducted using Lawrence and Friedman's theory, legal system from societal system theory, so that law includes three components: legal substance, legal structured and legal culture [13].

\section{Discussion}

In Indonesia, there is Republic of Indonesia Health Minister's Regulation Number 36 of 2015 about Fraud Prevention in the National Health Insurance Program in SJSN. The second paragraph explains about Fraud Prevention Team of JKN in Healthcare Facilities for Advanced-Level Treatment (thereafter called FKRT), so that Directors of Local General Hospitals in Central Java area should establish Fraud Prevention Team consisting of Team Leader (Chairperson of Internal Supervision Unit), Secretary: Chairperson of Service Division, Members: Chairperson of Medical Committee, Medical Recorder, Coder, and Chairperson of Treatment Committee. This team functions to detect earlier the fraud of JKN in Local General Service organization of Local General Hospital (thereafter called BLUD RSUD) based on the service claims made, to socialize new policy, regulation and culture oriented to quality control and cost control, to improve code, physician and other personnel's ability related to the claim, taking preventive measures, detecting, and acting on fraud of JKN, monitoring and evaluating, reporting to the Director of Local General Hospital once in six months.

The result of the study conducted in Central Java showed that some of healthcare service fraud has evidently occurred in Indonesia. Healthcare service fraud threats financial condition and lowers healthcare service. Data released by KPK (Corruption Eradication Commission) shows that potential fraud was detected from 175,774 FKRTL claims costing IDR 440 billion per June 2015 throughout Indonesia. It comes only from the clinician group, not from other actors such as BPJS Kesehatan staffs, patients, and health facility and drug suppliers. Perhaps, this value is not the total one, recalling a very simple supervision and detection system still used [14]. 
Central Java Subsidiary of BPJS's Chairperson says that fraud occurring in Local General Hospitals of Central Java includes: exaggerated diagnosis code writing/upcoding to get higher service, service unbundling or fragmentation, and changing inpatient treatment date. The preventive measures are as follows: healthcare service should be provided to the public maximally and oriented to quality control and cost control, service should be given corresponding to Standard Minimum Service (Indonesian: StandarPelayanan Minimal, thereafter called SPM), Clinical service guidelines and clinical pathway, clinical audit, and claim should be filed corresponding to the specified claim procedure.

Healthcare service fraud is getting more visible in Central Java. It is due to the pressure of the new funding system enacted in Indonesia, the presence of chance or opportunity because of limited supervision, and justification for doing this action. In Central Java, fraud among clinicians may be due to the imbalance between health service system and burden, service provider not giving adequate incentive, inadequate medical equipment supply, system inefficiency, less transparency in health facilities, and cultural factor. The firm sanction imposed to fraud perpetrator will result in deterrent effect (deterrent sanction). Health Minister's Regulation Number 36 of 2015 about Fraud prevention in healthcare service has mentioned administrative sanctions that can be imposed to fraud perpetrator. However, the sanctions have not been applied firmly yet. To optimize the fraud eradicating attempt, post-sanction imposition the perpetrators should be rebuilt and supervised as a means of building their awareness of not repeating their action.

\section{Conclusion}

Prevention system should be developed internally, reformed its governance and developed its internal supervision system. Every province should establish BPJS Supervision Council, and firm sanction should be imposed when fraud occurs in healthcare service.

\section{References}

1. Undang - Undang Republik Indonesia Nomor 36 Tahun 2009 tentang Kesehatan (Republic of Indonesia's Law Number 36 of 2009 about Health)

2. Undang - Undang Dasar Republik Indonesia 1945 (Republic of Indonesia's 1945 Constitution)

3. Kompasiana, Mengenal Potensi Fraud Pada Program Jaminan Kesehatan Nasional, Accessed At : http://www.kompasiana.com/moertjahjo58/mengenal-potensi-fraud-padaprogram-jaminan-kesehatan-nasional-jkn_54f433557455137e2b6c8a49 (2015)

4. Kitab Undang - Undang Hukum Dagang. (Weetbook van Koophandel voor Indonesie) Staatblad Tahun 1847 Nomor 23 (Indonesian Commercial Code of 1847 Number 23)

5. Harris SB dan Baker MT, Government turns up the heat with the False Claim Act steps for healthcare providers, Accessed At : www.dlapiper.com, (2014).

6. R. Nisbet, G. Miner, K. Yale D.D.S., J.D. Chapter 15 - Fraud Detection. Handbook of Statistical Analysis and Data Mining Applications (Second Edition), (2018)

7. S. Jou, B. Hebenton, Insurance fraud in Taiwan: Reflections on regulatory effort and criminological complexity. 35, 3, (2007)

8. A.C. Tobias, J.Kleinc. The effects of access to health insurance: Evidence from a regression discontinuity design in Peru, Journal of Public Economics, 154, Pp 122-136 (2017)

9. M. Kirlidog, C. Asuk, A Fraud Detection Approach with Data Mining in Health Insurance. Procedia,- Social and Behavioral Sciences, 62, (2012) 
10. Papa, Louis J. and Basile, Anthony, No-Fault Insurance Fraud: An Overview, Touro Law Review 17,3,8, (2016)

11. L.L.Pines, A.G.Safat, False Claims Act Litigation Post-Escobar, Practical Law, February/March (2018)

12. Data BPJS Kesehatantahun2015, downloaded at : https://bpjs-kesehatan.go.id/bpjs/, on May 25, 2018 at 15.00 Local Time

13. L.M. Friedman, The Legal System: A Sosial Science Perspective. (Russel Sage Foundation, New York, 1969)

14. Komisi Pemberantasan Korupsi (KPK), Accessed at : http://www.kpk.go.id. Retrieved on May 10, 2018 at 13.00 local time (2015) 